\title{
Sundanese Phonological Interference of The Recitation of Sura Al-Fatiha of The Holy Quran
}

\author{
Tatang \& Cucu Hayati \\ Universitas Pendidikan Indonesia \\ tatangupi@upi.edu
}

How to cite (in APA Style): Tatang, \& Hayati, C. (2018). Sundanese phonological interference of the recitation of sura Al-fatiha of the Holy Quran. Jurnal Pendidikan Bahasa dan Sastra, 18(2), doi:10.17509/bs_jpbsp.v18i2.15511

Article History: Received (18 July 2018); Revised (12 September 2018); Accepted (01 October 2018). Journal homepage: http:// ejournal.upi.edu./index.php/BS_JPBSP

\begin{abstract}
Culture is one of elements that affect a person's proficiency of foreign languages. Sundanese phonological structure is different from Arabic. Therefore, it is difficult for some Sundanese people to pronounce Arabic. For example, Sundanese tends to face difficulties in reciting the verses of the Holy Quran. The Holy Quran is the Muslims' holy book that is written in Arabic. The recitation of the Holy Quran should be in accordance with the Arabic phonology. In fact, Some Sundanese make irregularities or interference during reciting the Suras (chapters) of the Holy Quran. This study aims to reveal the phonological interference experienced by Sundanese speakers in reciting the Sura Al-Fatiba of the Holy Quran. The data in this study covers the recitations of the Sura Al-Fatiha. The data is retrieved through observation, recording, and interviews with some Sundanese people that live around the UPI Campus. The study concludes that there are five phonological interference phenomena in the pronunciation of the Hijāâ $\overline{1}$ (Arabic Alphabet) during the recitation of Sura Al-Fatiha. They are lenition, sound reinforcement, unusual sound changes, the voice addition, and assimilation. Some factors cause such interferences. They cover the influence of the Sundanese vocabulary and Arab phonemes that do not exist in the phonology of the Sundanese language.
\end{abstract}

Keywords: Interference, phonemes, sound changes, Makhärijul Hurüf, Sociolinguistics

\section{Interferensi Fonologis Bahasa Sunda dalam Pembacaan Surat Al-Fatihah pada Al-Qur'an}

\begin{abstract}
Abstrak: Budaya merupakan salah satu elemen yang mempengaruhi kemahiran seseorang dalam berbahasa asing. Struktur fonologis bahasa Sunda berbeda dari bahasa Arab. Karena itu, sulit bagi sebagian orang Sunda untuk mengucapkan bahasa Arab. Misalnya, bahasa Sunda cenderung menghadapi kesulitan dalam membaca ayat-ayat Al-Qur'an. Al-Qur'an adalah kitab suci umat Islam yang ditulis dalam bahasa Arab. Bacaan Alquran harus sesuai dengan fonologi Arab. Bahkan, beberapa orang Sunda membuat penyimpangan atau gangguan selama membaca Sura (bab) dari Al-Qur'an. Penelitian ini bertujuan untuk mengungkap gangguan fonologis yang dialami oleh penutur bahasa Sunda dalam melafalkan Sura Al-Fatiha dari Al-Qur'an. Data dalam penelitian ini mencakup bacaan Sura Al-Fatiha. Data diambil melalui observasi, rekaman, dan wawancara dengan beberapa orang Sunda yang tinggal di sekitar Kampus UPI. Studi ini menyimpulkan bahwa ada lima fenomena gangguan fonologis dalam pengucapan Hijầ' (Alfabet Arab) selama pembacaan Sura Al-Fatiha. Mereka adalah lenition, penguatan suara, perubahan suara yang tidak biasa, penambahan suara, dan asimilasi. Beberapa faktor menyebabkan gangguan tersebut. Mereka mencakup pengaruh kosakata bahasa Sunda dan fonem-fonem Arab yang tidak ada dalam fonologi bahasa Sunda.
\end{abstract}

Kata kunci: Interferensi, fonem, perubahan suara, Makhārijul Ḥurūf, Sosiolinguistik 


\section{INTRODUCTION}

Each language has unique configuration of phonemes that are different from other languages. Certainly, that makes Arabic and Sundanese phonemes different. Arabic has six vowels that are divided into short and long vowels. The short vowels consist of $a, i$, and $u$; and the long vowels consist of $\bar{a}, \overline{1}$, and $\bar{u}$. On the contrary, Sundanese has seven vowels. They are a, i, u, é, e, eu, and o. Both Arabic and Sundanese have similarity in phonemes a, i, and $u$. The differences are that Sundanese does not have long vowels; and that Arabic does not have vowels é, e, eu, and o. There are twenty ج، ح، خ، د، ذ، :

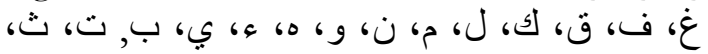
, In contrast, Sundanese has eighteen consonants: b, c, d, g, h, j, k, l, m, n, ny, ng, p, r, s, t, w, and y. Arabic consonants that do not exist in

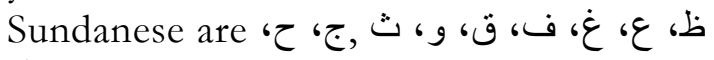

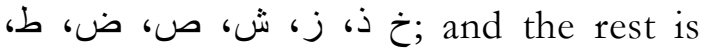
similar (Nuryantini, 2012,p. vii).

In addition, the Arabic phonology has differences with other languages. Salameh (2014, p.62) states that

The speech sound system of Arabic is very comprehensive. Considering the alphabets as the written symbols used for transcribing the phones of actual pronunciation, it has adequately covered the maximum number of sounds available in other languages. The human vocal system of articulator apparatus is a complete musical device and the elegance of this system has manifested itself to the fullest extent in the Arabic phonology. Thus, there are some sounds which are exclusively found only in the Arabic phonological system and not in any other language, such as $/ \mathrm{D} /, / \mathrm{DH} /, / \mathrm{S} /, / \mathrm{T} /$, although, we may come across some similar sounds there, but these are not well defined and distinguished from the aspect of articulation. If we consider that the primary task of phonology is to provide an objective description of speech, then the sound symbols or notational symbols of Arabic phonology are efficient description of possible variety of articulation and sound patterns.

Sundanese speakers, who are still dominated by Sundanese phonemes, and never learn Arabic, or the science of tajwid, will face difficulties in pronouncing Arabic phonemes that are not existed in Sundanese language. For instance, some Sundanese tend to pronounce alfatibah as alPätibab (the phoneme /f/ is turned into /p/). This happens because of the influence (phonological interference). Sundanese speakers find difficulties to pronounce the letter $F a$; and they find it easier to pronounce $\mathrm{Pa}$ (Suherman, 2012,p.23-24). Some of Sundanese speakers even pronounce alpätekah because they find difficulties to pronounce the letter $\boldsymbol{\tau}$. Another example is in the case of the word alladrina. Some Sundanese pronounce it alladina (the phoneme $/ \mathrm{dz} /$ is changed to $/ \mathrm{d} /)$. Both of these phonemes $(/ \mathrm{f} /$ and $/ \mathrm{dz} /$ ) are not on Sundanese phonemes.

The phenomenon is the focus of this research. If this phenomenon continues, it can be a habit. Moreover, reading Sura Al-Fatiha is one of the pillars of Muslim prayer. This study aims to determine how the sound changes due to phonological interference in the pronunciation of the Arabic alphabets contained in Sura Al-Fatiha, in the context of Sundanese speakers who spek languages with different phonemes as the contributing factors.

According to Alwasilah (1985,p. 131), based on the formula of Hartman and Stonk, interference is an error that is caused by the tendency to familiarize pronunciation (speech) of a language to another language. It includes pronunciations of sound units, grammar, and vocabulary. According to Chaer and Agustina (2010,p. 120), the term 
interference was first used by Weinreich to mention any changes in system of a language with regard to its contiguity with elements of other languages conducted by bilingual speakers. Interference refers to the existence of irregularities in the use of a language by inserting the system of other languages. For the purist, it is regarded as an error (Chaer and Agustina, 2010,p. 124).

Research on the phonological interference was ever undertaken by Hamzah and Busri (2015,p.1). They state that the pronunciation of Arabic words by speakers of other languages (in their case, Javanese and Sundanese) resulted deviations of sounds and rules. Their research shows that there are 69 words that were experienced phonological interference, from Javanese-Sundanese, and 12 letters that were pronounced with irregularities. There are four factors causing the findings: (1) the differences of alphabet, (2) the absence of one or more properties of letters in the speakers' mother tongue, (3) the similarities in the nature of letters, and (4) the adjacent makhroj position.

Some examples of Indonesian sound changes due to Sundanese phonological interference are (1) umlaut, the replacement of sound [i,«] by [if (C) where the word sabotase [sabotasi, «] is pronounced sabotaseu [sabotasï $f($ ] ; (2) assimilation, sound $[\mathrm{f}]$ is changed into $[\mathrm{p}]$ where the word [fakta] is pronounced [pakta]; (3) permutation, shifting the location of sound cluster [PR] where the pronunciation of the word [procedure] became [porsedUr] (Hamzah and Busri, 2015: 1).

The study discussed above has a different focus with this study. This study is focused on the irregularities of the pronunciation of Hijā'ì letters contained in Sura Al-Fatiha.

\section{METHOD}

The study used a qualitative approach. Bogdan and Taylor (in Moleong, 2009,p.9) defines qualitative research as research that produces descriptive data in the form of written or spoken words and behaviors of people that can be observed. The design of this study employed a descriptive design because the researcher will only describe and explain the phenomenon of phonological interference in pronunciation Sura AlFatiha by Sundanese speakers.

The data in this study covers the pronunciation of Sura Al-Fatiba made by Sundanese people. The data source of this research includes some Sundanese who live around UPI Campus. The sampling technique in this research employed purposive sampling where the researchers determine the sample with certain considerations and criteria in accordance with the purposes of research. The determined criteria determined that sample must be Sundanese; able to read the Holy Quran, in particular Sura AlFatiha; and have never studied the Quran intensively.

The data collection in this study used several methods and techniques below.

a. The oral test with observation method was focused on the data recording. It was aimed to determine the ability of participants (respondents) in reading Al-Fatiha; to find out the pronunciation of Hija $\bar{a} \overline{1}$ letters which are pronounced in reciting Al-Fatiha; to know the form of sound changes due to phonological interference in in reciting Al-Fatiba.

b. The interview was aimed to determine the factors that cause phonological interference in pronunciation of makharijul Hurüf of the Sura Al-Fatiha.

\section{RESULTS AND DISCUSSION}

This research has found 12 phonological interferences and 5 forms of sound changes in the pronunciation of Sura AlFatiha. The following will expose the findings in a sequence based on the level 
of difficulty of the letter pronounced by the participants.

Firstly, the deviation of the letters $/ \varepsilon /$ (') into $/ \mathrm{l} /$ (a) in the form of strengthening the sound of letters that are tawassuth baina rakhawah wa syiddah to the letters that are syiddah (strong), for example, the word العلمين be الألمين.

Secondly, phonological interference on the letter / $/$ / (h) into / 。 / (h) is the form of lenition of faringal makhraj into glottal makhraj, for instance, the word الرحمن الرحيم be الر همن الر هيم.

Thirdly, phonological interference on the letter/ق/ (q) into / J/ (k) is the form of lenition of makhorijul buruf/dorso-uvular/blast/voiced be makhorijul buruf/dorsovelar/blast/voiceless, for example, the word المستقيم be المستكيم.

Fourthly, phonological interference on the letter / $/ \dot{\varepsilon} /$ (ghin sukun) is reflected as qolqolah. The shape is in the form of abnormal sound change and or the addition of sound in the form of vowel eu of Sundanese, for instance, the word مغضوب is read maggeudhübi.

Fifthly, phonological interference on the letter ص/ش/ (s) into is the form of lenition of the letter that is isti'la (base of tongue is raised to palate) into the letter that is istifal (base of tongue is down to mouth ground), for example, the word صر اط is read شر اط.

Sixthly, phonological interference on the letter/ض/ (d) into / / (d) is the form of lenition of the letter that is isti'la and ithbaq (tongue cling to the palate) into the letter that is istifäl and infitah (tongue stretched). For instance, the word الضآلين (wa ladhdhällin) is read wa laddollin with the use of letter sound $د$ with additional vocal that does not exist in Arabic, the vowel $o$.

Seventhly, phonological interference on the letter /J/ (lam sukun) is reflected as the qolqolab letter. It is the form of abnormal sound change in Arabic and or sound addition in the form of addition of Sundanese vowel $e u$. For example, the word الحمد (alhamdu) is pronounced alleubamdu.

Eighthly, phonological interference on the letter ض in the word (wa ladh-dhöllin) into walabdhöllin. The change is an abnormal sound change and or the addition of consonant $b$.

Ninthly, phonological interference on the letter מص/ (s) into $/ \mathrm{w} /(\mathrm{s})$ is the form of lenition of makhroj buruf apicoalveolar/shear/voiceless/thick to be makbroj buruf /apicoalveolar/shear/voiceless/thin. The example is the pronunciation of the word سراط be صراط.

Tenthly, phonological interference on the letter $/ \mathrm{J} / \mathrm{dz}$ ) into / د/ (d) is the form of a sound reinforcement of makhorijul buruf /Apicointerdental/shear/voiced be makhorijul buruf /Apico-dental/blast/voiced/. The example is the word الذين be الدين.

Eleventh, phonological interference on the letter/ن/ (nun sukun) into /a/ (mim sukun) is the form of assimilation of adjacent makharijul buruf. The example is the word أنعمت is read

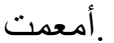

Twelfth, phonological interference on the letter / $/ \mathrm{w} /(\mathrm{s})$ into / (sy) is the form of a sound reinforcement of makhroj buruf /apicodental/shear/voiceless/ into /apicopalatal/shear/voiceless/. The example is the word نستعين be نشتعين.

In addition, after conducting interviews with several participants, it is concluded that there are four factors causing interference in the pronunciation of Sura Al-Fatiha by Sundanese speakers.

The first is knowledge factor. Participants mostly did not know how to pronounce Arabic letter based on Arabic phonology. They did not know how to pronounce the Arabic sounds that do not 
ث, ذ, ظ, ص, ط,

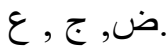

The second is the difficulty factor. Participants faced difficulties in contrasting letters that represent almostsimilar sounds, like $\varepsilon$ and $l, \tau$ and $\bullet$.

The third is training factor. Participants claimed that they had not practiced since childhood to familiarize correct pronunciation of Arabic alphabet.

The fourth is language factor. Participants speak Sundanese as their native language. It affects their pronunciation when they recite the Holy Quran. This is especially happen to those who have never learned how to pronounce Arabic phonemes correctly.

\section{Forms of Sound Changes Due to Phonological Interference in Recitation of Sura Al-Fatiha by Sundanese Speakers}

The phenomenon of Sundanese phonological interference in pronunciation of Arabic sounds during the recitation of Sura Al-Fatiba resulted sound changes. In connection with that, Crowley in Hadi, et al (2003: 121) mentions that sound changes can be in the form of (1) lenition, which consists of cluster removal or cluster reduction, apocope, syncope, haplology, and compression; (2) the sound addition, which consists of anaptyxis, epenthesis, and prothesis; (3) metathesis; (4) fusion;
(5) unpacking; (6) vowel breaking; (7) assimilation; (8) dissimilation; and (9) abnormal sound change.

However, this study only found four forms of sound changes. They include lenition, sound reinforcement, abnormal sound change, sound addition, and assimilation.

\section{A. Lenition}

Lenition is a linguistic phenomenon known in the form of phonemes that are articulated as "hard" on the front of the mouth, for example lip, but it turn into soft. The phoneme is then articulated at the esophagus. The sound occurs due to soft respiratory and sagging muscles. Sounds like $[\mathrm{d}, \mathrm{g}, \mathrm{z}]$ are Lenis. Soft sound (Lenis) is sound that is not accompanied by strong current tension at times it is articulated (Kridalaksana, 1984,p.127).

According to Hadi, et al., (2003,p. 122), voiced sounds (majhurab) are the sounds that are stronger than the unvoiced sounds (mahmūsah). Sounds like blast (infijar) are stronger than continuant sounds. The consonants are stronger than semi-vowels, the oral sounds are more powerful than the glottal sounds, and front and rear vowels are stronger than the central vowels. (1963: 92),

Similarly, according to Fattah

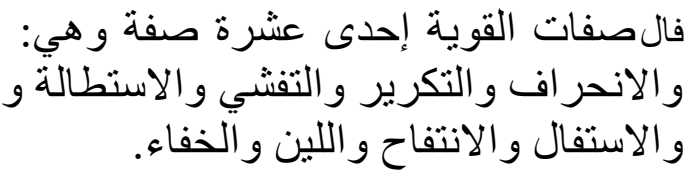

rakhawah (relax/soft), istifal (tip of tongue down to mouth base), infitah (stretched tongue), linn (soft), and alkhifä.

This study found a few examples of lenition from the data as follow.

1. Phonological interference of the letter $/ \mathrm{l} /(\mathrm{h})$ into $/ \% /(\mathrm{h})$ is the form of lenition of faringal to glottal. For example, the word الرحمن الرحيم is 
pronounced الرهمن الر هيم data coded II.TL.ASY.13-11-15, II.TL.L.13-1115, II.TL.R.13-11-15 and II.TL .C.1312-15).

2. Phonological interference of the letter / / (s) into / (s) is the form of lenition of makhroj/Apicoalveolar/shear/voiceless/thick/ into makhroj /Apicoalveolar/shear/voiceless/thin/. For example, the word صراط is pronounced سراط (data coded II.TL.L.13-11-15 and I.TL.A.24-1115).

3. Phonological interference of the letter / / (q) into / ك/ ( $\mathrm{k}$ ) is the form of lenition of makhorijul/dorsouvular/blast/voiced/ into makhorijul buruf /dorso-velar/blast/voiceless/. For example, the word المستقيم is pronounced المستكيم (data coded II.TL.L.13-11-15， II.TL.AN.13-1215, II.TL.C.13-12-15 and II.TL.R. 1311-15).

4. Phonological interference of the letter / (s) into / (sy) is the form of lenition of istila (tip of tongue is raised to palate) into istifal (tip of tongue down to the mouth base). For instance, the word صراط is pronounced شراط (data coded II.TL.C.13-12-15, II.TL.E.13-11-15, and II.TL.ASY.13-11-15)

5. Phonological interference of the letter / / (dha) to / / (d) is the form of lenition of istila and ithbaq (tongue cling to mouth roof) into istifaal and infitala (tongue stretched). For example, the word ولا الضآلين (wa ladhdhällin) is read wa laddollin with the use of sounds $د$ with additional vowel $o$ that does not exist in Arabic (data coded II.TL.C.13-12-15, II.TL.E .1311-15 and I.TL.A.24-11-15).

\section{B. Sound Reinforcement}

Sound reinforcement means the form of sounds changes from relatively weaker sounds into relatively stronger sounds. This type of changes is the opposite of lenition (Hadi. Et al, 2003: 127). The study found several examples of sound reinforcement as follow.

1. Sound Irregularity of the letter / $\varepsilon /(')$ into $/ \mathrm{I} /$ (a) is the form of strengthening the sound that is rakhawah (relax) into the letter that is infijariyah (blast). For example, the word الألمين data coded II.TL.Y.08-11-15, II.TL.L.0811-15, II.TL.R.08-11-15 and I.TL.A .15-11-15)

2. Phonological interference of the letter $/ \mathrm{J} /(\mathrm{dz})$ into $/ \mathrm{J} /$ (d) is the form of strengthening the sound of makhorijul /Apico-interdental /shear/voiced/ into makhorijul /Apicodental/blast/voiceless/. For instance, the word الدين is pronounced (data coded II.TL.L.13-11-15).

3. Phonological interference of the letter / / (s) into / (sy) is the form of sound reinforcement o makhroj /apicodental/shear/voiced/ into /apicopalatal/shear/voiceless/. For example, the word نستعين is pronounced نشتعين (data coded II.TL.C.13-12-15).

\section{Abnormal Sound Change and Sound Addition}

According to Crowley, in Hadi et al (2003: 121), one of the sound changes is the abnormal sound change. In this case, it means an unusual sound change is heard in the pronunciation of the Arabic phonology. Another sound change is the sound addition. This study, therefore, has found the two forms of sound changes because of phonological interference.

1. Phonological interference on the letter /J/ (lam sukun) is reflected as the qolqolah letter. It is the form of abnormal sound change in Arabic and or sound addition in the form of addition of Sundanese vowel $e u$. For example, the word الحمد (alhamdu) is pronounced alleubamdu (data coded 
II.TL.L.13-11-15 and II.TL.R.13-1115).

2. Phonological interference on the letter $/ \dot{\varepsilon} /$ (ghin sukun) is reflected as qolqolah. The shape is in the form of abnormal sound change and or the addition of sound in the form of vowel en of Sundanese, for instance, the word مغضوب (maghdhubi) is read maggeudhübi (data coded II.TL.L.1311-15, II.TL.R.13-11-15, II.TL.AN.13-12-15 and II .TL.E.1312-15).

3. phonological interference on the letter ض و لا الضآلين in the word ladb-dhöllin) into walabdhollin. The change is an abnormal sound change and or the addition of consonant $b$ (data coded II .TL.L.13-11-15 and II.TL.R.13-11-15).

\section{Assimilation}

Assimilation is a process of sound changes that result close sounds (Kridalaksana, 1984, p.17). The assimilation process was found in the phonological interference on the letter /ن/ (nun sukun) into / / / mim sukun) is the form of assimilation of adjacent makharijul huruf. The example, in the data coded II.TL.L.08-11-15, is the word أنعمت read أمعدت.

The results show that seven Sundanese speakers pronounce the letters $\tau, \varepsilon, \boldsymbol{\varepsilon}, \ddot{,}, \boldsymbol{\omega}, \dot{\jmath}$, and $\dot{\varepsilon}$, incompatible with Arabic phonological system. It is because according to some theories and previous researches, those letters are not Sundanese phonemes. According to Nuryantini (2012,p. 105-106), there are some differences between Arabic and Sundanese phonemes. To be mentioned, Arabic has long vowels, whereas Sundanese has no one. Sundanese has vowels é, e, eu, and o; whereas Arabic does not have them. In terms of the place of articulation, manner of articulation, and the state of the vocal cords; the pronunciation differences between consonants of Arabic and Sundanese are

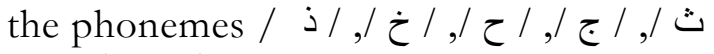

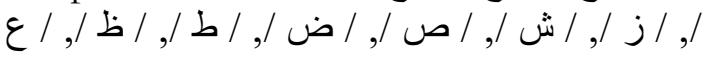
 nasal /ny/ and /ng/, while Arabic does not have them. In Arabic, there are interdental consonants like ظ, ذ, ث; while in Sundanese, there is no one. In Arabic, there are $i t h b \bar{a} q$ letters that are spoken with the curled shape of the tongue like / ط, ظ, ص, ض/ while Sundanese there is no same phonemes.

The following is the description of some Arabic letters that are not contained in the Sundanese phonemes.

\section{ض. Letter ض}

In the letter ض pronunciation, the participants who made inaccurate sound tend to pronounce it as $د$, or even with the addition of sound $b$ when ض has sukun. Though the letter ض is considered ithbaq letter; and the letter $د$ is considered infitah letter.

According to Hijazi (nd, p. 43),

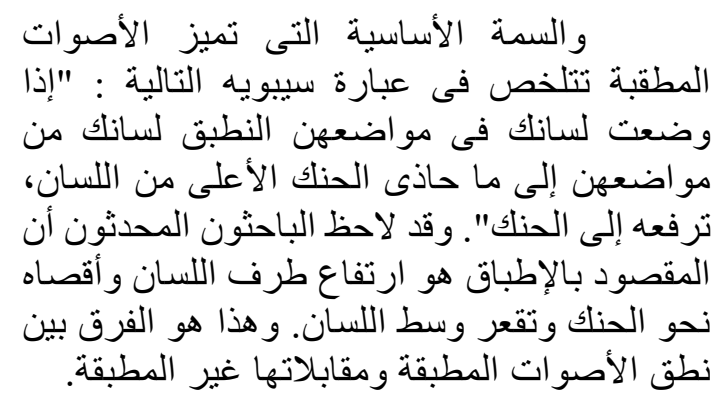

If you put your tongue in a variety of positions in line with the upper ceiling of mouth, you should lift it to the ceiling. The language researchers have observed that the Ithbaq letters are produced by elevating/lifting base and tip of tongue towards the middle of the tongue. It is the difference of pronunciation between the Ithbaq letter and other letters.

According to Fattah (1963,p. 82), infitah letter is 


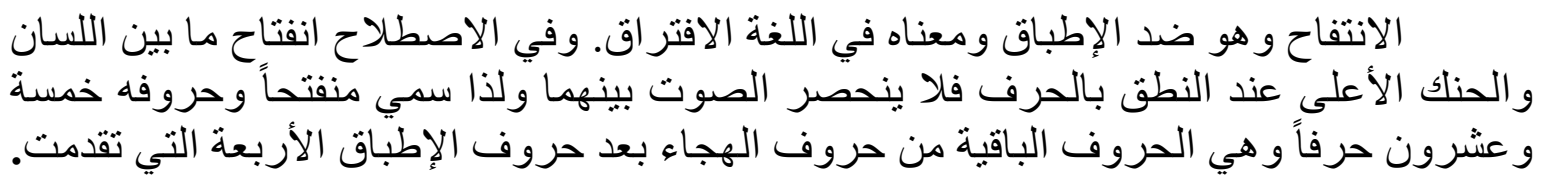

Infitah is the opposite of ithbaq. Semantically, their meaning is separated. Etymologically, Infitah is the opening of the space between the tongue and palate when letter is pronounced. Therefore, sound is not muffled between them. Therefore, these properties are called properties infitah. They are 25 letters that are not included the ithbaq letters.

Based on makhraj, both sounds are derived from the same spot, namely allisan (makhraj of letters located on tongue). However, the nature of the letter ض is different from the letter د because ithbaq is the reverse of infitah. Sundanese people tend to mispronounce the letters and are often confused.

\section{B. Letter ص}

Five participants made inaccurate pronunciation of the letter ص. Based on the observations, two participants were confused when pronouncing the letters $\omega$ and ص; and three participants were confused when pronouncing the letters ش ص ص ص ص .

The following is the description of letters according to Hijazi (tt: 43).

1. Letter $ص$ is a Shafir sound (sound from the tip mouth as it knotted) and the inverse of sound between the teeth like $b$ and teeth sound like $b$.

2. Letter ص is the sound attached to the tongue (ithbaq) and it is the opposite of the sound w.

3. The way to read it is by hams (without getting out of breath) and it is not a phonological reference of the fusha Arabic system; and it is not found in fusha Arabic. It is read by jahr.

\section{Letter $\varepsilon$}

Five participants made inaccurate pronunciation of the letter $\varepsilon$. Based on the observations, the five participants were confused when pronouncing the letters $I$ and $\varepsilon$.

According to Nasution (2012,p. 20-34), the following are the differences between the two letters.

1. The letter $\varepsilon$ is included in the group of faringal makhroj (الحلقية), while $I$ is included in the group of glottal letters (الحنجرية).

2. In terms of the nature, the letter $\varepsilon$ is included relax consonant (رخاوة) while $I$ is included blast consonant (الإنفجارية).

\section{Letter $\tau$}

The almost similar phenomenon can be found in the participants who made inaccurate pronunciation of pronouncing $\tau$. Based on the observations, they are confused when pronouncing the letter $\tau$ and $\bullet$.

According to Nasution (2012,p.20-34), the differences between the two letters is that The letter $\tau$ is included in the group of faringal makhroj (الحلقية), while $\bullet$ is included in the group of glottal letters (الحنجرية).

\section{E. Letter}

Four participants made inaccurate pronunciation of the letter ق. Based on the observations, the five participants were confused when pronouncing the letters 3 and 5 . According to Yusuf (2012,p. 18) the letter قis included Isti'la (base of tongue is raised to palate) while the letter 5 is included Istifal (base of tongue is down to mouth ground).

\section{G. Qolqolah Letter}

Participants made inaccurate pronunciation of the non-qolqolab letters into qolqolab letters. For example, the 
word الحمد is pronounced alleuhamdu; and the word مغضوب is pronounced maggeudhübi. According to Fattah (1963, p. 83), there are only 5 qolqolab letters: b,, , and $د$.

\section{و القلقلة صفة لازمة لحروفها الخمسة المذكورة آنفاً ولا فرق بين أن يكون الساكن منها موصو لاً

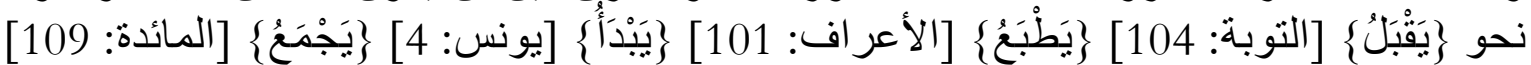

From the description of the letters above, it is clear that there are differences among the letters. The letters even have opposite nature. However, based on the observation, participants were still confused to distinguish them.

\section{The Causes of Phonological Interferences in the Recitation of Sura Al-Fatiha by Sundanese Speakers}

Based on the interviews, all participants have difficulties in pronouncing the letter ض. Based on the participants' self-evaluation, the contributing factor is the influence of their native language. The data is in line with the opinion of Weinreich (in Ngatipan, 2014,p.23-27) that the interference is carried over in the habit of using the mother tongue. Habits of mother tongue that affect the performance of new language generally occurs due to the lack of language control and lack of the language mastery. This can occur in the bilinguals who are learning a second language, both national and foreign languages. Moreover, the data is in accordance with $\mathrm{Lu}$ (2010) that the inaccuracy is caused by linguistic interactions or transfer of experience, where there are language habits that have been established and are difficult to change.

Native language habits affect the inaccuracy in reading the Sura Al-Fatiba of the Holy Quran. This is true and backed by some opinions and previous researches. Nuryantini, (2012,p.105-106) mentions that Sundanese has no

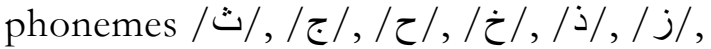

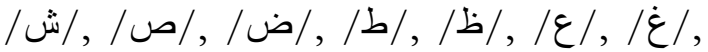

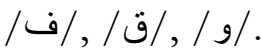

Participants assume that learning the Arabic pronunciation is tough. Another factor is the lack of exercise. One participant claimed to not practice since childhood to be able to pronounce the Arabic phonemes correctly. This is in line with the opinion of Suherman (2012,p. 7) as follow.

1. Students often find it difficult to say Arabic sounds that do not exist in their native language.

2. Students heard some vague Arabic sounds that resembles the sounds in his mother tongue, and together with their teacher, the students locate the sound differences.

3. Students often do mistakes in recognizing what they have heard. Therefore, their pronunciation is based on their hearing.

4. Students often do mistakes in recognizing differences between some Arabic sounds; and they think it is not important because the measurement is based on their mother tongue. They cannot distinguish ذ, س

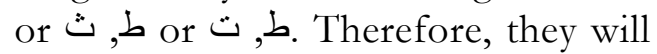
shift the sounds based on their hearing.

5. Students find it difficult to pronounce the sounds of Arabic, as well as letters with certain behaviors. Therefore, they find it difficult to imitate the sounds of ذ.

6. Among the sounds that are difficult to be perceived by non-Arabic speakers 
are ض, ط, ظ, ص. The sounds are considered heavy or softened/folded is pronounced with tafhim, folding or twisting. The students also find it difficult to distinguish

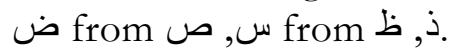

7. Students also face difficulties to distinguish $\dot{\tau}$ and $\dot{\varepsilon}$.

8. Non-Arabic speakers find it difficult to distinguish $\bullet$ and. $\tau, \varepsilon, \varepsilon, \varepsilon$,

Inaccuracy in the pronunciation of Arabic sounds is also influenced by the assumption of the participants themselves. They assume that it is difficult to learn the Arabic phonemes. They regard the inaccuracy as tolerable. Nasution (2012,p. 67) mentions that one of the causes of the language inaccuracy is a wrong assumption about a foreign language.

Some participants of this study do not know the rules or the rules of Arabic sounds. Of course, it affects their Arabic pronunciation because they do not know the rules. According to Nasution (2012: 68), one of the causes of language imprecision is incomplete application.

\section{CONCLUSION}

Based on the discussion, this study concludes that there are 12 phonological interference phenomena in the pronunciation of Sura Al-Fatiba by Sundanese speakers. The interferences are divided into five forms of sound changes. The first is lenition, as phonological interference in the letter / / (h) into / / (h), the letter / / (s)

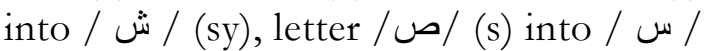
(s), letter/ق/ (q) into /s/ (k), and the letter / / (dh) into / / (d). the second is sounds reinforcement, like the inaccuracy of sounds (phonological

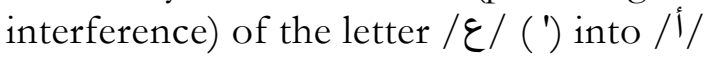
(a), the letter $/ \mathrm{J} /(\mathrm{dz})$ into $/ \mathrm{J} / \mathrm{d}$ ), and the letter / / (s) into / ش/ (sy). Trhe third is abnormal sound change, such as phonological interference of the letter /J/ (lam sukun) and /غं/ (Ghin sukun) pronunciation that are reflected as qolqolah -alleubamdu and maggeudhubi-. The fourth is the sound addition, like phonological interference of the pronounciation of (wa ladhdhöllin) that is pronounced walabdhöllin, extra phonemes $b$. the fifth is assimilation, as in phonological interference of the letter/ن/ (nun sukun) into / / / (mim breadfruit).

There are four factors that cause phonological interference in the of Sura Al-Fatiha by Sundanese speakers: 1) lack of knowledge of Arabic phonemes, 2) the difficulty in pronouncing the Arabic phonemes that do not exist in Sundanese phonemes, 3) the lack of exercise in pronouncing Arabic phonemes correctly, and 4) the routine of Sundanese phonemes since early childhood period.

Thus, it is expected that the Sundanese people who have not studied makharijul huruf to not get discouraged; and keep trying to improve the Holy Quran recitation, especially Sura Al-Fatiha which is one of the pillars of prayer.

\section{REFERENCES}

Alwasilah, A. C. (1985). Beberapa madhab dan dikotomi teori linguistik. Bandung: Angkasa.

Chaer, A., \& Agustina, L. (2010). Sosiolinguistik perkenalan awal. Jakarta: Rineka Cipta.

Fattah, A. (1963). Hidaayatu Al-Qoorii ilaa Tajwiidi Kalaami Al-Baari. Madinah Al-Munawwaroh: Maktabah Thayyibah (Maktabah Syaamilah).

Hadi, S., et al. (2003). Perubahan Fonologi Kata-Kata Serapan dari Bahasa Arab dalam Bahasa Indonesia. Humaniora. 15(2). 121-132

Hamzah, K., \& Busri, H. (2015). Interferensi Fonologis Jawa-Sunda Masyarakat Kedungreja Cilacap Pada Penuturan Bahasa Arab. Journal of Arabic learning and Teaching, $4(1), p 1-7$

Hijazi, M.F. (n.d). Madkhal ilaa 'Tlmi alLughoh. Mesir: DaaruQubaa’. 
Kridalaksana, H. (1984). Kamus Linguistik. Jakarta: Gramedia.

Lu, L. (2010). Language transfer: from topic prominence to subject prominence. University of Leeds, United Kingdom.

Moleong, L.J. (2009). Metodologi penelitian kualitatif. Bandung: CV Remaja Rosdakarya.

Nasution, A. S. A. (2012). Fonetik dan Fonologi Al-Qur'an. Jakarta: Amzah.

Ngatipan. (2014). Interferensi dalam Kemahiran Kalam dan Qira"eah Siswa MTs Negeri Rongkop Gunungkidul. Tesis pada Program Pasca Sarjana UIN Sunan Kalijaga Yogyakarta: unpublished.

Nuryantini, A. (2012). Analisis Kontrastif antara Fonem Bahasa Arab dan Bahasa Sunda serta Implikasinya dalam Pengajaran Bahasa Arab. Paper at the Faculty of Tarbiyah and Teacher Training, State Islamic University of Sunan Kalijaga Yogyakarta: unpublished.

Salameh, M.Y.B. (2014). The Phonetic Nature of Vowels in Modern Standard Arabic. Advances in Language and Literary Studies, 5(4), p.60-67

Suherman, A. (2012). Perubahan Fonologis Kata-kata Serapan Bahasa Sunda dari Bahasa Arab: Studi Kasus pada Masyarakat Sunda di Jawa Barat, Indonesia. Sosiobumanika. 5(1), p.21-38.

Yusuf, M. (2012). Buku Panduan Bimbingan Baca Al_Quran jilid III Baitul Quran Daarut Taubiid. Bandung: unpublished. 